九州大学学術情報リポジトリ

Kyushu University Institutional Repository

\title{
Histological Observation of the Somatic Embryogenesis in Dieffenbachia 'Anna'
}

\section{Shen, Rong-Show}

Department of Horticultural Science, National Chiayi University

Jian, You-Lin

Department of Horticultural Science, National Chiayi University

Lee, Yung-I

Department of Biology, National Museum of Natural Science

Huang, Kuang-Liang

Department of Horticultural Science, National Chiayi University

他

https://doi.org/10.5109/1564072

出版情報: 九州大学大学院農学研究院紀要. 61 (1)，pp. 1-6，2016-02-29. Faculty of Agriculture， Kyushu University

バージョン :

権利関係 : 


\title{
Histological Observation of the Somatic Embryogenesis in Dieffenbachia 'Anna'
}

\author{
Rong-Show SHEN ${ }^{1 *}$, You-Lin JIAN ${ }^{1}$, Yung-I LEE ${ }^{2}$, \\ Kuang-Liang HUANG ${ }^{1}$ and Ikuo MIYAJIMA ${ }^{3}$ \\ Institute of Tropical Agriculture, Kyushu University, Fukuoka 812-8581, Japan \\ (Received October 28, 2015 and accepted November 19, 2015)
}

\begin{abstract}
In this study, a procedure for the histological observation of the somatic embryogenesis in Dieffenbachia 'Anna' was developed. Thin slices of secondary somatic embryos (SSEs) were used as explants. Somatic embryogenesis tended to be derived from a single cell. Upon further differentiation, the single cell became an embryogenic cell mass, and somatic embryos (SEs) subsequently formed under the influence of 3 , 6-dichloro-2-methoxybenzoic acid (dicamba) and 1-phenyl-3-(1, 2, 3-thiadiazol-5-yl) urea (TDZ). The cytological origin and early proembryoid differentiation process were initiated after 6 days of culture. A single embryogenic cell initiated asymmetric cell division to form an apical cell and basal cell. A two-celled proembryo subsequently developed from the basal cell, forming a three-celled proembryo. After 9 days of culture, the apical cell underwent anticlinal division, and prior the two cells of periclinal division to form a T-shaped four-celled proembryo. After 12 days of culture, the cells continued to divide and formed an eightcelled proembryo. After 15-18 days of culture, 8-10 cells formed a rudimentary proembryo, revealing the primary structure of the embryo. After 24 days of culture, a 16-celled proembryo was formed. The multicellular embryoid had formed within the explants, which gradually emerged to the surface of the explants. Each embryoid exhibited a thick cell wall, isolated with the surrounding cells from the embryonic base of the suspensor construction. After 27 days of culture, the proembryo emerged from the explant surrounding, and the early globular embryoid with protoderm. After 12 weeks of culture, the explants in the original medium formed embryoid clusters with various developments were visible. Histological observation showed that the globular embryos separated from the explants, with distinct protoderm and Y-shape closed procambium. During the development of the somatic embryos, an asynchronous phenomenon was observed in the mature embryo stage of the scutellum and coleoptilar embryos, but not when the mature somatic embryos converted to emblings.
\end{abstract}

Key words: asymmetric division, early proembryoid differentiation, embryogenic cell, foliage plant

\section{INTRODUCTION}

Dieffenbachia is a genus of monocotyledon in the Araceae family that is native to the Caribbean. Possessing characteristics such as sophisticatedly varied emerald leaves, high shade tolerance, and easy cultivation, Dieffenbachia is widely used in indoor landscape, and is considered as one of the most popular and essential indoor foliage plants worldwide (Chou, 1989).

Previously, Dieffenbachia was micropropagated using axillary bud cultures (Shen and Lee, 2009b; 2014; Taylor and Knauss, 1978). Hu and Huang (1997) used newly unfolded leaves of Dieffenbachia maculata 'Rudolph Roehrs' as explants to induce callus formation, thereby obtaining adventitious buds. This regeneration system was also applied to mutation breeding. In somatic embryogenesis, using male inflorescences of Dieffenbachia as explants induces the genesis of embryogenic callus and proliferation and somatic embryos. After embling conversion, complete plants are formed (Shen and Lee, 2007; 2009a; 2015).

Department of Horticultural Science, National Chiayi University, Chiayi 60004, Taiwan, ROC.

Department of Biology, National Museum of Natural Science, Taichung 404, Taiwan, ROC.

Institute of Tropical Agriculture, Kyushu University, Fukuoka 812-8581, Japan.

* Corresponding author (E-mail address: garden@mail.ncyu. edu.tw, telephone: +88652717431 fax: +88652775472$)$
Totipotency is a crucial competence of plant cells, enabling them to retain the parental genetic information for re-differentiation into a complete plant (Fortes and Pais, 2000). SEs are bipolar that are produced from somatic cells without undergoing gamete fusion and undergo a development process similar to that of zygote embryos (Quiroz-Figueroa et al., 2006; Namasivayam, 2007). SEs show several advantages in mass multiplication, such as high efficiency, easy to culture in liquid medium, and substantial yield. Furthermore, SEs can be cultured by bioreactors, and are crucial production in artificial seeds and transgenic plants (Merkle et al., 1990). SE is derived from a nonzygote cell; an individuals that possess identical characteristics as its parent plant can be obtained because of genetic stability (Gaj, 2004). Studying somatic embryogenesis not only reveals the mechanism of differentiation, development, and morphology as well as zygote embryo development, but also provides a cytological basis for further optimizing the somatic embryogenesis system and expanding its application in plant breeding. Currently, a rapid clonal micropropagation system for Dieffenbachia somatic embryogenesis has been established (Shen and Lee, 2009a; 2015); however, no study has investigated the histology of early somatic embryogenesis. Therefore, the present study used thin slices of Dieffenbachia embryogenic cell clumps to perform SE induction and to observe the histology of early somatic embryogenesis, thereby clarifying the cytological origin and early proembryo development 
of Dieffenbachia.

\section{MATERIALS AND METHODS}

\section{Explant Source and Culture Medium Composition}

In this study, explants were obtained from 3-4 mmthick slices of in vitro SSE clumps of Dieffenbachia 'Anna' (Fig. 1), which were cultured at the Tissue Culture Laboratory of National Chiayi University. The culture medium was based on that adopted by Shen and Lee (2009a), with young male-inflorescences used as explants to induce the formation of SE clusters. The culture medium composition was as follows: A half-strength modified MS (Murashige and Skoog, 1962) medium with $20 \mathrm{~g} \cdot \mathrm{L}^{-1}$ sucrose (Sigma-Aldrich Co., USA), $10 \mathrm{~g} \cdot \mathrm{L}^{-1} \mathrm{glu}-$ cose (Sigma-Aldrich Co., USA), and $1.8 \mathrm{~g} \cdot \mathrm{L}^{-1}$ Gelrite (Supremacy Instrument Co., Taipei, Taiwan) was used as the basal medium. Treatments of $2 \mathrm{mg} \cdot \mathrm{L}^{-1}$ of 3 , 6-dichloro-2-methoxybenzoic acid (dicamba) (SigmaAldrich Co., China), in combination with $1 \mathrm{mg} \cdot \mathrm{L}^{-1}$ of 1-phenyl-3-(1, 2, 3-thiadiazol-5-yl) urea (TDZ) (SigmaAldrich Co., China) were supplemented to the basal medium for somatic embryogenesis induction. Before sterilization, the $\mathrm{pH}$ value of medium was adjusted to 5.5. Each test tube $[140 \mathrm{~mm}(\mathrm{ht}.) \times 25 \mathrm{~mm}$ (dia.) flatbottomed round tube] contained $10 \mathrm{~mL}$ culture medium and was sterilized at $121^{\circ} \mathrm{C}, 1.05 \mathrm{~kg} \cdot \mathrm{cm}^{-2}$ for $20 \mathrm{~min}$ in an autoclave.

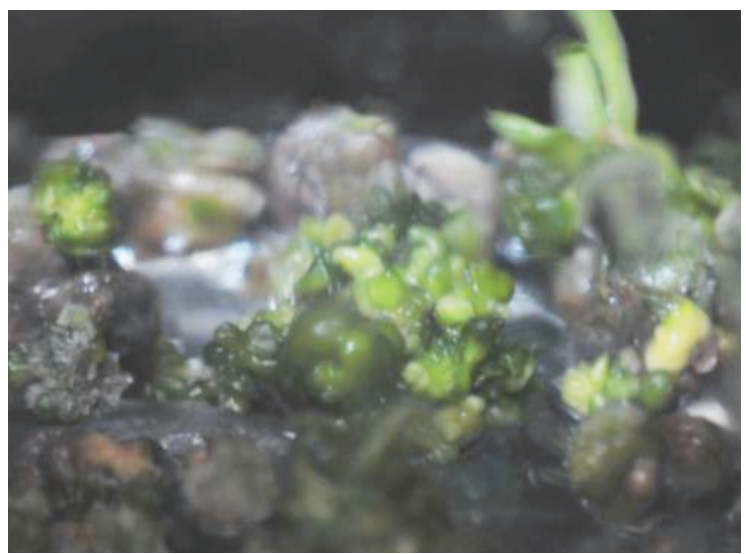

Fig. 1. Clusters of secondary somatic embryos in Dieffenbachia 'Anna'.

\section{Experiment Method}

The SE clumps of Dieffenbachia 'Anna' were cut into slices 3-4 mm thick after the SEs separated from primary explant. These sliced tissues were placed on the culture medium for test. The culture room was controlled at a constant temperature of $25 \pm 1^{\circ} \mathrm{C}$. The cool-white fluorescent lamp (TFC-FL40D/38, Taiwan) was used as the light source to provide a photosynthetic photon flux $(\mathrm{PPF})$ of $35 \pm 5 \mu \mathrm{mol} \cdot \mathrm{m}^{-2} \cdot \mathrm{s}^{-1}$. The photoperiod was set to a $16 \mathrm{~h} / 8 \mathrm{~h}$ light/dark cycle. The growth of explants was recorded every 3 days from day 0 to day 27. An optical stereoscopic microscope (Olympus SZX-12, Japan) was used to obtain photographic records. In addition, plastic-embedded sections were adopted to observe somatic embryo development. Resin sections were prepared as follows: Callogenesis from dedifferentiation of embryonic tissues were cut into $2 \mathrm{~mm}$ thick slices, which were then fixed for $16 \mathrm{~h}$ at $4^{\circ} \mathrm{C}$ in $2.5 \%$ glutaraldehyde (prepared by diluting 50\% glutaraldehyde stock with $0.2 \mathrm{M} \mathrm{pH} 7.2$ phosphate buffer). Subsequently, 0.1 M pH 7.2 phosphate buffer was used to wash the samples three times. A series of dehydration steps was then performed. The samples were first dehydrated for 20 min independently by using $15 \%, 30 \%$, and $50 \%$ alcohol, and were then dehydrated separately for 30 min by using 70\%, 80\%, and $90 \%$ alcohol. Finally, the samples were dehydrated three times by using 100\% alcohol. Infiltration was performed to the samples three times by using alcohol and LR White Resin (London Resin Co. Ltd, England) at ratios of $3: 1,1: 1$, and $1: 3$ respectively. Infiltration was then performed three times using $100 \%$ resin. The samples were embedded in LR White Resin according to the manufacturer's instructions. After being isolated from air, the samples were heated for polymerization in an oven at $65^{\circ} \mathrm{C}$. Subsequently, an ultramicrotome (Reichert Ultracut S., Leica Microsystems, Wetzlar, Germany) and glasscutter were used to cut the samples into $1 \mu \mathrm{m}$ thick slices. After the samples were stained for $1 \mathrm{~min}$ on a hot plate at $70^{\circ} \mathrm{C}$ by using $0.1 \%(\mathrm{w} / \mathrm{v})$ alkaline toluidine blue $\mathrm{O}$ (diluted with benzoate buffer), the microscope was used to obtain photographic observation and records.

\section{RESULTS}

After the sliced tissues of SSE clumps of Dieffenbachia 'Anna' were cultured in 1/2 MS medium containing $20 \mathrm{~g} \cdot \mathrm{L}^{-1}$ sucrose, $10 \mathrm{~g} \cdot \mathrm{L}^{-1}$ glucose, $3 \mathrm{~g} \cdot \mathrm{L}^{-1}$ Gelrite, $2 \mathrm{mg} \cdot \mathrm{L}^{-1}$ dicamba, and $1 \mathrm{mg} \cdot \mathrm{L}^{-1} \mathrm{TDZ}$, embryogenic callus and SEs were formed after 6 days of culture (Fig. 2). After 24 days of culture, calli proliferated actively, covering the entire surface of the explants and exhibiting a light yellow color. These were embryogenic calli (Fig. 2A). After 27 days of culture, light-yellowish white somatic embryos formed, presenting a smooth surface with notching at the tip (Fig. 2B). After the explants were cultured for 12 weeks in the original culture medium, SE clusters were formed. These embryoids, including globular-, scutellum-, and coleoptilar-shaped embryoids, at various development stages coexisted simultaneously (Fig. 2C). However, a browning phenomenon was observed in the basal portion of the embryoid clusters (figure not shown).

The histological observation revealed that the somatic cells were activated after sliced tissues of Dieffenbachia embryonic explants were cultured for SE induction. Cell layers near the incision developed into calli, and their inner cells transformed into embryogenic cells, which further developed into SEs (Fig. 3 and 4). The individual somatic cells of the explants transformed into embryonic tissue in the presence of a growth regulator, further developing into SEs. The process of origin was as follows. Six days after culture, a single cell initiated the first cell division, forming into a two-cell proembryo, which further developed into an apical cell and a basal cell through 

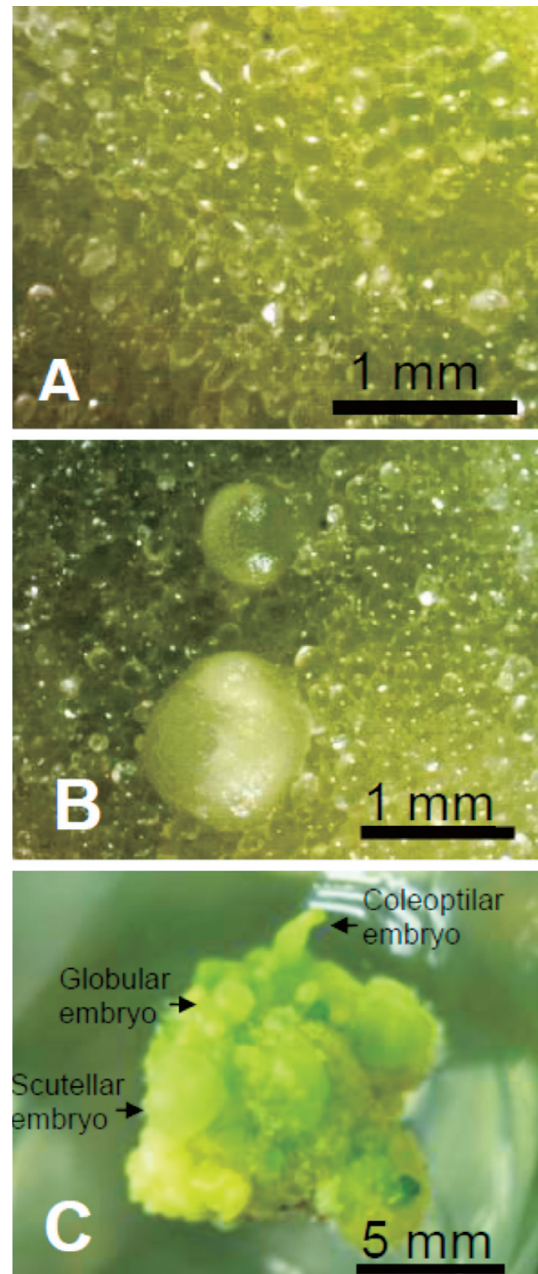

Fig. 2. Formation of embryogenic calli and somatic embryogenesis in Dieffenbachia 'Anna'

(A) A close-up image of calli formed after 24 days of culture. (B) Globular embryos arise on the surface of the explant after 27 days of culture. (C) Clustered somatic embryos formed after 12 weeks of culture, with the development of globular, scutellar and coleptilar embryos visible. periclinal division (Fig. 3A). The basal cell of the twocell proembryo underwent the second cell division (Fig. 3B), forming a three-cell proembryo (Fig. 3C). Nine days after culture, a T-shaped four-cell proembryo (Fig. 3D) was developed following two periclinal divisions and one anticlinal division of the apical cell. Between 15 and 18 days after culture, a multicellular proembryo comprising 7-8 cells was formed, revealing a suspensor (Fig. 3E). After 24 days of culture, a multicellular proembryo comprising approximately 13 cells was developed, exhibiting visible cell polarity and consisting of suspensor formed after three periclinal divisions and the proper of globular embryo above the suspensor (Fig. 3F). After 27 days of culture, a multicellular proembryo comprising 16-18 cells was developed. Anticlinal division occurred in the embryo proper, forming SEs (Fig. 3G). In addition, another fourcell proembryo shaped differently from the T-shaped proembryo was observed, and the four cells were symmetrical in size, exhibiting no visible polarity (Fig. 4A and B). Random anticlinal and periclinal divisions were subsequently performed, causing the proembryo to develop into 6-8 cells and eventually forming into an embryonic clump (Fig. 4D). Through the histological observation of the 24-day explants, various stages of proembryos were found to develop simultaneously (Fig. 5), including 2-, 3-, 4-, and 8-cell proembryos and numerous embryonic cells with visible nucleoli. Such an asynchronous phenomenon was commonly observed during somatic embryogenesis.

A histological observation was performed on the SEs visible by visual inspection. After 27 days of explant culture, globular embryos that protruded the explant showed early protoderm structures, but were yet to form procambium (Fig. 6A). After 12 weeks of subculture, globular embryos that were separated from explants developed clear protoderm and closed Y-shaped provascular
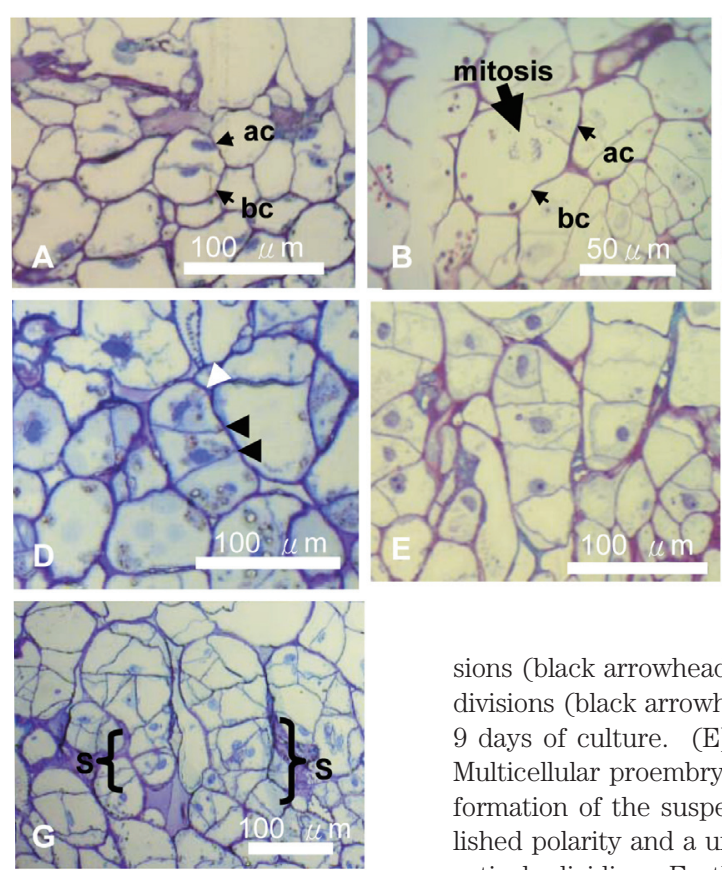
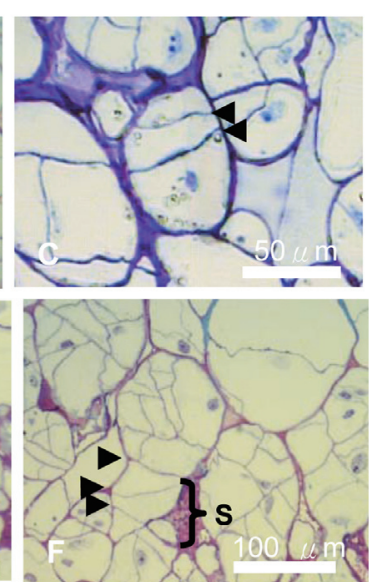

Fig. 3. Histology of early differentiation of somatic embryogenesis in Dieffenbachia 'Anna'

(A) Two-celled proembryo formed through the periclinal division (black arrowhead) of the somatic cell after 6 days of culture. The first cell division of the somatic cell resulted in the formation of an apical cell (ac) and basal cell (bc). (B) The second cell division within the two-celled proembryo. The mitotic apparatus (arrow) is located toward the basal cell. (C) A three-celled proembryo created through two periclinal divisions (black arrowhead) of the somatic cell. (D) Four-celled proembryo formed through two periclinal divisions (black arrowhead) followed by anticlinal division (white arrowhead) within the apical cell after 9 days of culture. (E) A multicellular proembryo comprising 7-8 cells with the suspensor (S). (F) Multicellular proembryo (13 cells visible). Three periclinal divisions (black arrowhead) resulted in the formation of the suspensor (S). (G) Multicellular proembryo (16-18 cells visible) with clearly established polarity and a uniseriate suspensor as well as cells in the apical region (embryo proper) that are actively dividing. Furthermore, many periclinal and anticlinal divisions of the suspensor resulted in the formation of somatic embryos after 27 days of culture. SG: starch grain. 


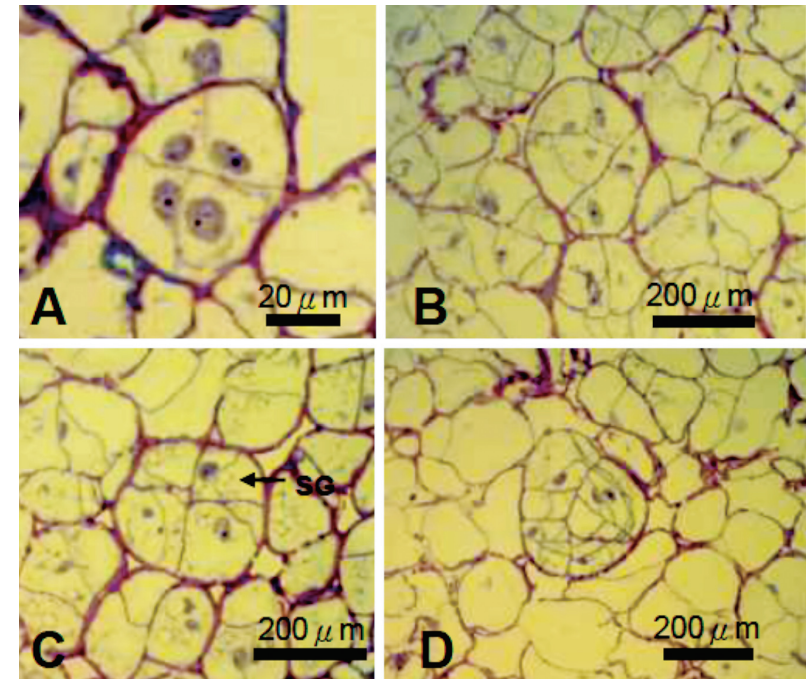

Fig. 4. Histology of embryogenic cell masses differentiation in Dieffenbachia 'Anna'

(A) Four-celled proembryo. (B) Proembryo containing 6-7 cells. (C) An eight-celled proembryo formed by divisions in random planes. (D) Continued divisions would result in an embryogenic cell mass. SG: starch grain.

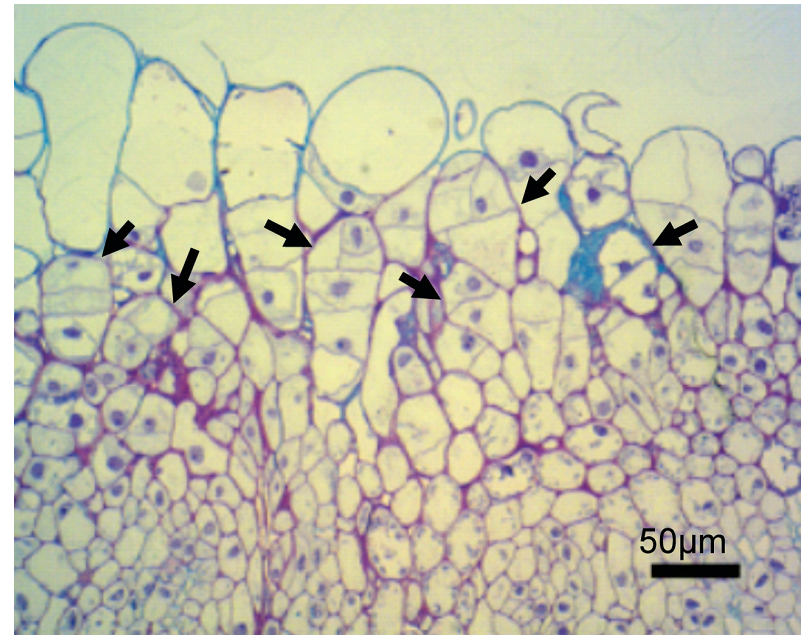

Fig. 5. Histology of unsynchronized somatic embryo differentiation after 24 days of culture in Dieffenbachia 'Anna'

Two-, three-, four-, and eight-celled proembryos (arrow) emerged from the explant inner after 24 days of culture.

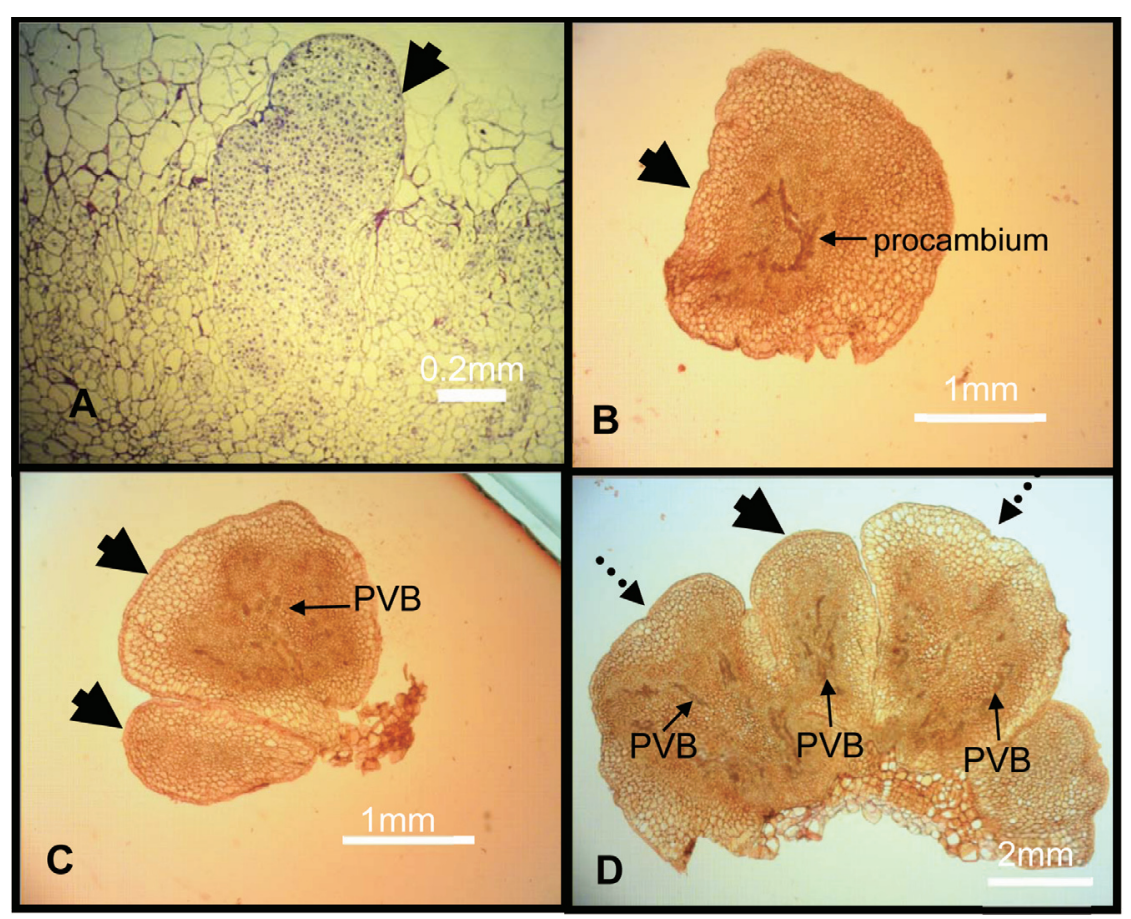

Fig. 6. Histological observation of early proembryos, globular embryos, and scutellar embryos in Dieffenbachia 'Anna'

(A) Globular embryo stage with protoderm (arrow) after 27 days of culture. (B) Individual globular embryo, visible protoderm (arrow) formation and procambium initiation. (C) Globular embryo, protoderm and closed provascular bundle (PVB) formation. (D) Cluster somatic embryos, visible protoderm and provascular bundle formation; the mature somatic embryos had an elongated with a notch on the top of scutellum (dotted arrow).

bundles (PVB) (Fig. 6B and 6C). Because of the asynchronous somatic embryogenesis, globular and scutellum embryos existed simultaneously, with both possessing protoderm and PVB. In addition, notches were detected at the top of scutellum embryos, where coleoptile were likely to form (Fig. 6D).

\section{DISCUSSION}

Shen and Lee (2015) indicated that using the young male-inflorescences of Dieffenbachia as explants can induce the formation of embryogenic calli and SEs. Moreover, multiplication of SSE enables a highly efficient 
embling conversion into complete plants. However, no study has examined the histological origin of early somatic embryogenesis. This study adopted the SSE of Dieffenbachia 'Anna' as explants. Because this type of embryo proliferates rapidly, the entire process of somatic embryogenesis can be observed in a short time. Morphological observation showed that under the induction by dicamba and TDZ, slices tissues of SSEs first developed into embryogenic callus (Fig. 2A). After 27 days of culture, a globular embryo was formed, exhibiting preliminary protoderm (Fig. $2 \mathrm{~B}$ and $6 \mathrm{~A}$ ), which further developed into clusters of SE clumps (Fig. 2C). In addition, histological observation of the Dieffenbachia somatic embryogenesis showed that after induction, a single cell obtained embryogenic competence and subsequently underwent periclinal division into a two-cell proembryo comprising an apical cell and basal cell (Fig. $3 \mathrm{~A})$. Cell division was subsequently activated in the proembryo to form three-cell, four-cell, and multicellular proembryos as well as globular embryos with protoderm (Fig. 3B and 3C). The observation proved that the direct somatic embryogenesis of Dieffenbachia originated from a single cell, providing further evidence regarding the single-cell origin of somatic embryogenesis. Related reports on single-cell origin have examined the direct somatic embryogenesis of other species (Rugkhla and Jones, 1998; Quiroz-Figueroa et al., 2002; Mandal and Gupta, 2003). The first step in embryonic development is the initiation of polarity (Wilson and Wilson, 1993). Krikorian (1989) proposed that the asymmetric division of the initial cell established the growth axis of the cell plane, representing the bipolarity development. In the four-cell proembryo stage, the basal cell underwent periclinal division to develop a suspensor comprising two cells, whereas the apical cell underwent anticlinal division to form a two-cell proembryo. Thus, a T-shaped proembryo exhibiting visible polarity was produced (Fig. 3D). In the 13-cell proembryo stage, the suspensor was developed from three periclinal divisions (Fig. 3F). The structure was similar to that of the 14-cell proembryo of Deschampsia caespitosa grass (Vasilenko et al., 2000). Furthermore, a non-T-shaped four-cell proembryo was also observed. After disordered cell division, this proembryo developed into an embryonic clump (Fig. 4), which was referred to by Haccius (1978) as a proembryonal cell complex, from which one or multiple SEs were subsequently developed. Similar reports have been published on related histological observations of D. caespitosa (Trigiano et al., 1989; Vasilenko et al., 2000) and Coffea arabica (Quiroz- Figueroa et al., 2002).

A histological observation of Dieffenbachia somatic embryogenesis revealed that the single cell that developed into a proembryo was an inner cell of the explant. Induced by dicamba and TDZ, the cell developed into embryogenic cells, advancing toward SE development. Before embryonic induction, cells in the secondary somatic embryogenic cell clumps were large and had unobvious nuclei (figure not shown). However, after required the embryonic competence, the somatic cells converted into smaller embryogenic cells containing obvi- ous nuclei and rich starch grains (Fig. 3 and 4). Dos Santos et al. (2006) indicated that the immature zygote embryo tissues of Glycine Max were mostly preembryogenic determined cells (PEDCs). After embryonic induction, no callus was formed; instead, the SE was developed directly from single epidermal cell. A similar result was obtained by using immature zygote embryos of Arabidopsis as explants for embryonic induction (Kurczynska et al., 2007). Cells in the SSE clumps were likely PEDCs, and developed into embryogenic determined cells (EDCs) after the cell competence was adjusted through embryonic induction, further developing into SEs.

Because of the asynchronous phenomenon observed in Dieffenbachia somatic embryogenesis, several multicellular proembryos with various levels of development were simultaneously observed in an explant (Fig. 5). Furthermore, formations of globular, scutellum, and coleoptilar embryos were also found in embryoid clusters (Fig. 3C). Under the effects of various physical or chemical factors, plant cells achieved totipotency through dedifferentiation and redifferentiation. During this process of somatic embryogenesis, a single cell initiated cell division, causing quiescent cells in the $\mathrm{G}_{0}$ phase to reenter cell division. The cells entered their cell cycles at different times, thus their development phases varied, resulting in asynchronous somatic embryogenesis (Li et al., 2007), which was a common problem that is difficult to avoid.

The present study verified that the somatic embryogenesis of Dieffenbachia 'Anna' originated from a single somatic cell. The first cell division was periclinal division, which was crucial to cell polarity and subsequent SE formation. The T-shaped four-cell proembryo underwent further cell division, forming multicellular bipolar proembryos that contained an embryo proper and suspensor. In the globular embryo stage, the embryoid separated from the explant, and possessed visible protoderm and closed Y-shaped PVB. This embryoid continued to develop into a mature coleoptilar embryoid. However, after 12 weeks of culture, the mature somatic embryos did not convert into emblings. Additional tests and verifications must be conducted to elucidate the conditions in which embling conversion occurs.

\section{ACKNOWLEDGEMENTS}

This study was supported by a grant from Agriculture and Food Agency, Council of Agriculture, Executive Yuan, Taiwan, ROC. 96AS-1.1.1-FD-Z2(6) and 97AS1.1.1 -FD-Z2(3). We are also grateful to Mr. Yao-Lung Tsai for help investigating.

\section{REFERENCES}

Bodanese-Zanettini. 2006 Somatic embryogenesis from immature cotyledons of Soybean (Glycine $\max$ (L.) Merr.): Ontogeny of somatic embryos. Braz. Arch. Biol. Technol. 49: 49-55

Chou, M. Y. 1989 Effect of temperature, light intensity, and mineral nutrition on propagation, growth, and interior display quality of Dieffenbachia. MS Thesis, Dept. of Hort., Natl. Taiwan 
Univ. Taipei

Fehèr, A., T. P. Pasternak, K. Otvos, P. Miskolczi, and D. Dudits. 2002 Induction of embryogenic competence in somatic plant cells: A review. Biologia 57: 5-12

Gaj, M. D. 2004 Factors influencing somatic embryogenesis induction and plant regeneration with particular reference to Arabidopsis thaliana (L.) Heynh. Plant Growth Regulat. 43: $27-47$

Haccius, B. 1978 Question of unicellular origin of non-zygotic embryos in callus cultures. Phtommorphology 28: 74-81

Hu W. J. and M. C. Huang. 1997 The study of primary culture of Dieffenbachia maculata Schott (Lodd.) G. Don. 'Rudolph Roehrs'. Hort. NCHU. 22: 95-108

Krikorian, A. D. 1989 Polarity establishment, morphogenesis and cultured plant cells in space. p. 87-95. In: J. D. Sibonda, R. C. Mains, T. N. Fast, P. X. Callahan and C. M. Wingle (eds.). NASA Conf. Pub.

Kurczyńska, E. U., M. D. Gaj, A. Ujczak, and E. Mazur. 2007 Histological analysis of direct somatic embryogenesis in Arabidopsis thaliana (L.) Heynh. Planta 226: 619-628

Li, T. T., J. S. Shi, J. H. Chen, L. M. Bian, Z. Chen, and C. Wu. 2007 Developmental synchronization of somatic embryogenesis under suspension culture condition. Mol. Plant Breeding 5: $436-442$

Mandal, A. K. A. and S. D. Gupta. 2003 Somatic embryogenesis: influence of auxin and ontogeny of somatic embryos. Plant Cell Tiss. Org. Cult. 72: 27-31

Merkle, S. A., W. A. Parrot, and E. G. Williams. 1990 Applications of somatic embryogenesis and embryo cloning. pp. 67-101. In: Bhojwani, S.S. (ed.). Plant Tissue Culture: Applications and Limitations. Elsevier, Amsterdam

Murashige, T. and F. Skoog. 1962 A revised medium for rapid growth and bioassays with tobacco tissue cultures. Physiol. Plant. 15: 473-497

Namasivayam, P. 2007 Acquisition of embryogenic competence during somatic embryogenesis. Plant Cell Tiss. Org. Cult. 90: $1-8$

Quiroz-Figueroa, F. R., C. F. J. Fuentes-Cerda, R. Rojas-Herrera, and V. M. Loyola-Vargas. 2002 Histological studies on the developmental stages and differentiation of two different somatic embryogenesis systems of Coffea arabica. Plant Cell Rpt. 20: 1141-1149

Quiroz-Figueroa, F. R., R. Rojas-Herrera, R. M. Galaz-Avalos, and V. M. Loyola- Vargas. 2006 Embryo production through somatic embryogenesis can be used to study cell differentiation in plants. Plant Cell Tiss. Org. Cult. 86: 285-301

Rugkhla, A. and M. G. K. Jones. 1998 Somatic embryogenesis and plantlet formation in Santalum album and S. spicatum. J. Expt. Bot. 49: 563-571

Shen, R. S. and N. Lee. 2007 Effect of auxin concentration on somatic embryogenesis from male inflorescence of Dieffenbachia 'Tiki'. J. Taiwan Soc. Hort. Sci. 53: 451-463

Shen, R. S. and N. Lee. 2009a Cytokinins stimulate somatic embryogenesis and plant regeneration from male inflorescence of Dieffenbachia 'Tiki'. Agric. Assoc. Taiwan 10: 380-388

Shen, R. S. and N. Lee. 2009b Increasing lateral bud production with 6-benzylaminopurine and antibiotics pretreatments on establishment of aseptic culture for axillary explants in Dieffenbachia spp. J. Agr. For. (NCYU) 5: 87-105

Shen, R. S. and N. Lee. 2014 The methods for avoiding endo-contamination of shoot-tip explants in initial culture of dieffenbachia. J. Taiwan Soc. Hort. Sci. 60: 77-87

Shen, R. S. and N. Lee. 2015 High efficient somatic embryo multiplication and embling conversion of Dieffenbachia 'Tiki'. J. Taiwan Soc. Hort. Sci. 61: 81-94

Trigiano, R. N., D. J. Gray, B. V. Conger and J. K. McDaniel. 1989 Origin of direct somatic embryos from cultured leaf segments of Dactylis glomerata. Bot. Gaz. 150: 72-77

Vasic, D., G. Alibert and D. Skoric. 2001 Protocols for efficient repetitive and secondary somatic embryogenesis in Helianthus maximiliani (Schrader). Plant Cell Rpt. 20: 121-125

Vasilenko, A., J. K. McDaniel and B. V. Conger. 2000 Ultrastructural analyses of somatic embryo initiation, development and polarity establishment from mesophyll cells of Dactylis glomerata. In Vitro Cell Dev. Biol. 36: 51-56

Warren Wilson, J. and P. M. Warren Wilson. 1993 Mechanism of auxin regulation of structural and physiological in plants, tissues, cells and embryos. Aust. J. Plant Physiol. 20: 555-571 